\title{
Faktor Risiko yang Berhubungan dengan Kejadian Anemia pada Remaja Putri
}

\author{
Mahmut Jaelani $^{1}$, Betty Yosephin Simanjuntak ${ }^{2}$, Emy Yuliantini $^{3}$ \\ ${ }^{1,2,3}$ Jurusan Gizi, Politeknik Kesehatan Kementrian Kesehatan Bengkulu \\ Email: mahmut.jaelani777@gmail.com
}

\begin{abstract}
Risk Factors Associated with The Incidence of Anemia in Teenager Girls. Teenage girls are one of the groups who are prone to anemia. Anemia in teenage girls is still a big public health problem because the prevalence is still $\geq 20 \%$ that is equal to $21,7 \%$. This study aimed to examine the dominant factors associated with the incidence of anemia and determinants in teenage girls in MTsN 02 Kota Bengkulu with a cross-sectional design. The population was all female adolescents in MTsN 02 Kota Bengkulu and the sample was taken by using simple random sampling as much as 100 respondents taken from class VII and class VIII. The results showed that the anemia was $33.0 \%$ and there was a relationship between menstrual period $(p=0,028)$, nutritional status $(\mathrm{p}=0,000)$, breakfast habits $(\mathrm{p}=0,000)$, iron intake $(\mathrm{p}=0,000)$, intake protein $(\mathrm{p}=0,017)$, consumption pattern of iron absorption inhibitor $(\mathrm{p}=0,045)$ and there was no significant correlation between maternal education level $(\mathrm{p}=0,265)$ with incidence of anemia in Young women at MTsN 02 Kota Bengkulu. Variable nutritional status is the most dominant associated anemia in young women.
\end{abstract}

Keywords: Anemia, Education, Menstruation, Intake, Breakfast, Nutritional status

\begin{abstract}
Abstrak: Faktor Risiko yang Berhubungan dengan Kejadian Anemia pada Remaja Putri. Remaja putri merupakan salah satu kelompok yang rawan menderita anemia. Anemia pada remaja putri masih menjadi masalah kesehatan masyarakat yang besar karena prevalensinya masih $\geq 20 \%$ yaitu sebesar $21,7 \%$. Penelitian ini bertujuan untuk mengkaji faktor-faktor dominan berhubungan dengan kejadian anemia dan determinan pada remaja putri di MTsN 02 Kota Bengkulu dengan desain cross-sectional. Populasi adalah seluruh remaja putri di MTsN 02 Kota Bengkulu dan sampel diambil dengan menggunakan simple random sampling sebanyak 100 responden yang diambil dari kelas VII dan kelas VIII. Hasil penelitian menunjukkan bahwa kejadian anemia sebesar 33,0\% dan terdapat hubungan antara lama haid $(p=0,028)$, status gizi $(p=0,000)$, kebiasaan sarapan pagi $(p=0,000)$, asupan zat besi $(p=0,000)$, asupan protein $(p=0,017)$, pola konsumsi inhibitor penyerapan zat besi $(p=0,045)$ dan tidak terdapat hubungan yang bermakna antara tingkat pendidikan ibu $(p=0,265)$ dengan kejadian anemia pada remaja putri di MTsN 02 Kota Bengkulu. Variabel status gizi merupakan yang paling dominan berhubungan kejadian anemia pada remaja putri.
\end{abstract}

Kata kunci: Anemia, Pendidikan, Haid, Asupan, Status gizi

Saat ini terdapat empat masalah gizi remaja yang utama di Indonesia yaitu Kekurangan Energi Protein (KEP), Anemia Gizi Besi (AGB), Gangguan Akibat Kekurangan Yodium (GAKI), dan Kekurangan Vitamin A (KVA). Diantara empat masalah gizi diatas yang sering terjadi sampai saat ini adalah AGB pada remaja remaja putri (Almatsier S, 2009).

Anemia pada remaja dapat membawa dampak kurang baik bagi remaja, anemia yang terjadi dapat menyebabkan menurunnya kesehatan reproduksi, perkembangan motorik, mental, kecerdasan terhambat, menurunnya prestasi belajar, tingkat kebugaran menurun, dan tidak tercapainya tinggi badan maksimal (Andriani M. dan Wirjatmadi B, 2013).
Prevalensi nasional anemia di Indonesia berdasarkan data Riskesdas (2013), yaitu mencapai $21,7 \%$. Proporsi kejadian anemia di Indonesia menurut karakteristik jenis kelamin perempuan lebih mendominasi jika dibandingkan dengan laki-laki, presentasi pada perempuan $23,9 \%$ dan laki-laki $18,4 \%$ serta berdasarkan karakteristik kelompok umur 5-14 tahun lebih tinggi jika dibandingkan dengan remaja umur 1521 tahun, pada umur 5-14 tahun 26,4\% kejadian anemia dan umur 15-21 tahun $18,4 \%$ kejadian anemia (Kemenkes RI, 2013).

Penelitian Suryani D, dkk (2015) mengemukakan prevalensi anemia pada remaja putri di kota Bengkulu sangat tinggi yaitu mencapai 43\%. Kemenkes RI (2013), 
menyebutkan anemia pada remaja putri menjadi masalah kesehatan bila prevalensinya $20 \%$, sehingga perlu untuk melakukan penelitian lanjutan untuk mengetahui pokok permasalahan anemia pada remaja putri di kota Bengkulu.

Arisman (2010), menyebutkan terdapat 3 penyebab anemia defisiensi besi: 1) kehilangan darah secara kronis; 2) asupan zat besi dan penyerapan yang tidak adekuat; 3) peningkatan kebutuhan asupan zat besi untuk pembentukan sel darah merah yang lazim berlangsung pada masa pubertas. Anemia juga dapat disebabkan adanya faktor-faktor lain seperti lama haid, kebiasaan sarapan pagi, status gizi, pendidikan ibu, asupan zat besi dan protein tidak sesuai dengan kebutuhan serta adanya faktor inhibitor penyerapan mineral zat besi yaitu tanin dan oksalat.

Penelitian Febrianti, dkk (2013), menemukan hubungan yang bermakna antara lama haid dengan kejadian anemia pada remaja putri. Remaja putri dengan lama haid $>6$ hari dalam 1 siklus memiliki risiko anemia lebih rendah jika dibandingkan dengan remaja putri yang mengalami haid $>6$ hari. Dibuktikan dengan hasil uji statistik dengan $p$-value $=0,28$.

Penelitian Kalsum U dan Halim R (2016), menyebutkan kebiasaan sarapan pagi adalah penyebab salah satu faktor risiko anemia karena sarapan pagi menentukan remaja untuk mendapatkan pola konsumsi yang baik sebagai bekal aktivitas sehari-hari sehingga terhindar dari anemia.

Penelitian Martini (2015) faktor yang mempengaruhi kejadian anemia yaitu status gizi dan tingkat pendidikan ibu. Status gizi dalam kategori kurus mempunyai risiko 3,1 kali mengalami anemia dibandingkan dengan remaja yang status gizinya normal dan ibu yang berpendidikan rendah, kurang memperhatikan makanan yang dikonsumsi anaknya dan kurang memperhatikan pemenuhan kebutuhan gizi seimbang. Bagi keluarga dengan tingkat pendidikan yang tinggi akan lebih mudah menerima informasi kesehatan dan mampu menerapkan dalam kehidupan sehari-hari.

Tujuan penelitian ini untuk mengetahui faktor-faktor yang berhubungan dengan kejadian anemia pada remaja putri di MTsN 02 Kota Bengkulu.

\section{METODE}

Penelitian ini merupakan penelitian analitik dengan rancangan penelitian cross sectional. Rancangan penelitian ini digunakan untuk mengetahui faktor-faktor yang berhubungan dengan kejadian anemia pada remaja putri di MTsN 02 Kota Bengkulu. Populasi penelitian adalah semua remaja putri remaja putri kelas VII dan kelas VIII. Besar sampel berjumlah 100 responden. Sampel diperoleh dengan menggunakan teknik simple random sampling. Pengumpulan data dilakukan dengan pengukurandan menyebarkan kuesioner.

Metode pengukuran dilakukan untuk mengumpulkan data variabel anemia dengan alat ukur hemoglobinometer digital (Easy Touch $\mathrm{GCHb}$ ) variabel lama haid dengan kuesioner, lama kebiasaan sarapan pagi dengan kuesioner, asupan zat besidan protein form recall $2 \times 24$ jam, status gizi remaja putri dengan indikatorIMT/U melalui alat ukur timbangan dan microtoise (alat pengukur tinggi badan) serta pola konsumsi makanan inhibitor penyerapan zat besi dengan food frequency questionnaires. Analisis data menggunakan analisis univariat, analisis bivariat menggunakan uji chi square dengan selang kepercayaan (confident interval) 95\% dan tingkat kesalahan $(\alpha)$ 0,05 dan multivariat menggunakan regresi logistik dengan selang kepercayaan mengeliminasi variabel yang tidak mempunyai kekuatan hubungan dengan tingkat kesalahan $(\alpha)$ 0,25 .

\section{HASIL}

\section{Karakteristik Responden}

Tabel 1.Karakteristik Respoden

\begin{tabular}{lrr}
\hline \multicolumn{1}{c}{ Variabel } & \multicolumn{2}{c}{ Frekuensi } \\
\cline { 2 - 3 } & n & \% \\
\hline Kejadian Anemia & & \\
Anemia (jika nilai $\mathrm{Hb}<12 \mathrm{~g} / \mathrm{dL})$ & 33 & 33.0 \\
Tidak Anemia $(\mathrm{Hb} \geq 12 \mathrm{~g} / \mathrm{dL})$ & 67 & 67.0 \\
Lama haid & & \\
Tidak normal & 27 & 27,0 \\
Normal & 73 & 73,0 \\
Status gizi & & \\
Tidak normal & 43 & 43,0 \\
Normal & 57 & 57,0 \\
Kebiasaan Sarapan & & \\
Tidak baik & 39 & 39,0 \\
Baik & 61 & 61,0 \\
Pendidikan Ibu & & \\
Rendah & 92 & 92,0 \\
Tinggi & 8 & 8,0 \\
Asupan Zat Besi & & \\
Tidak tercukupi & 70 & 70,0 \\
Tercukupi & 30 & 30,0 \\
Asupan Protein & & \\
Tidak tercukupi & 45 & 45,0 \\
Tercukupi & 55 & 55,0 \\
Pola konsumsi makanan inhibitor & & \\
penyerapan zat besi & & \\
Sering & 54 & 54,0 \\
Jarang & 46 & 46,0 \\
\hline
\end{tabular}


Hasil penelitian menunjukkan bahwa gambaran, sebagian besar remaja putri $(67,0 \%)$ lebih banyak tidak anemia dibandingkan remaja putri anemia, lama haid sebagian besar remaja putri $(73,0 \%)$ dengan kategori haid normal, status gizi sebagian besar remaja putri $(57,0 \%)$ dengan kategori status gizi normal, kebiasaan sarapan pagi sebagian besar remaja putri $(61,0 \%)$ dengan kategori baik, pendidikan ibu remaja putri sebagian besar mempunyai ibu dengan pendidikan rendah yaitu sebanyak $92,0 \%$, asupan zat besi remaja putri $(70,0 \%)$ sebagian besar dengan kategori asupan zat besi tidak tercukupi, asupan protein remaja putri $(55,0 \%)$ sebagian besar dengan kategori tercukupi dan pola konsumsi makanan inhibitor penyerapan zat besi remaja putri $(54,0 \%)$ sebagian besar dengan kategori sering.

\section{Faktor-faktor yang Berhubungan dengan Kejadian Anemia}

Hasil uji statistik analisis bivariat untuk mengetahui hubungan variabelindependen dengan kejadian anemia pada remaja putri melalui uji chi square dengan $\alpha=0,05$ diperoleh faktor-faktor yang teliti berhubungan semua secara bermakna, yaitu lama haid ( $p=0,028$; OR 3,061 CI 95\%: 1,222-7,667), status gizi (IMT/U) $(p=0,000 ;$ OR 5,405 CI $95 \% \quad 2,179-13,405)$, kebiasaan sarapan pagi ( $p=0,000$; OR $11,83 \mathrm{CI}$ 95\%: 2,395-31,848), pendidikan ibu(p=0,265), asupan zat besi ( $p=0,000$ OR 24,421 CI 95\%: $3,319-189,35)$, asupan protein $(p=0,000$ OR 5,481 CI 95\%: 2,319-14,731) dan pola konsumsi makanan inhibitor penyerapan zat besi $(\mathrm{p}=2,671$ OR 2,671 CI 95\%: 1,103-6,466) (Tabel 2).

Tabel 2. Faktor-faktor yang Berhubungan dengan Kejadian Anemia Remaja Putri

\begin{tabular}{|c|c|c|c|c|c|c|c|c|}
\hline \multirow{3}{*}{ Variabel } & \multirow{3}{*}{ Kategori } & \multicolumn{6}{|c|}{ Kejadian Anemia } & \multirow{3}{*}{ Nilai $p$} \\
\hline & & \multicolumn{2}{|l|}{ Ya } & \multicolumn{2}{|c|}{ Tidak } & \multicolumn{2}{|c|}{ Jumlah } & \\
\hline & & $\mathrm{n}$ & $\%$ & $\mathrm{n}$ & $\%$ & $\mathrm{n}$ & $\%$ & \\
\hline \multirow[t]{2}{*}{ Kejadian Anemia } & Anemia & 14 & 51,9 & 13 & 48,1 & 27 & 100,0 & \multirow{2}{*}{0,028} \\
\hline & Tidak Anemia & 19 & 26,0 & 54 & 74,0 & 73 & 100,0 & \\
\hline \multirow[t]{2}{*}{ Lama haid } & Tidak Normal & 23 & 53,5 & 20 & 46,5 & 43 & 100,0 & \multirow{2}{*}{0,000} \\
\hline & Normal & 10 & 17,5 & 47 & 82,5 & 57 & 100,0 & \\
\hline \multirow[t]{2}{*}{ Status gizi } & Tidak baik & 25 & 64,1 & 14 & 35,9 & 39 & 100,0 & \multirow{2}{*}{0,000} \\
\hline & Baik & 8 & 13,1 & 53 & 86,9 & 61 & 100,0 & \\
\hline \multirow[t]{2}{*}{ Kebiasaan Sarapan } & Rendah & 32 & 34,8 & 60 & 65,2 & 92 & 100,0 & \multirow{2}{*}{0,265} \\
\hline & Tinggi & 1 & 12,5 & 7 & 87,5 & 8 & 100,0 & \\
\hline \multirow[t]{2}{*}{ Pendidikan Ibu } & Tercukupi & 1 & 3,3 & 29 & 96,7 & 30 & 100,0 & \multirow{2}{*}{0,000} \\
\hline & Tidak Tercukupi & 32 & 45,7 & 38 & 54,3 & 70 & 100,0 & \\
\hline \multirow[t]{2}{*}{ Asupan Zat Besi } & Tercukupi & 9 & 16,4 & 46 & 83,6 & 55 & 100,0 & \multirow{2}{*}{0,000} \\
\hline & Tidak tercukupi & 24 & 53,3 & 21 & 46,7 & 45 & 100,0 & \\
\hline \multirow[t]{2}{*}{ Asupan Protein } & Sering & 23 & 42,6 & 31 & 57,4 & 54 & 100,0 & \multirow{2}{*}{0,046} \\
\hline & Jarang & 10 & 21,7 & 36 & 78,3 & 46 & 100,0 & \\
\hline \multirow{2}{*}{$\begin{array}{l}\text { Pola konsumsi makanan inhibitor } \\
\text { penyerapan zat besi }\end{array}$} & Sering & 23 & 42,6 & 31 & 57,4 & 54 & 100,0 & \multirow{2}{*}{0,046} \\
\hline & Jarang & 10 & 21,7 & 36 & 78,3 & 46 & 100,0 & \\
\hline
\end{tabular}

Faktor Dominan yang Berhubungan dengan Kejadian Anemia Remaja Putri

Hasil penelitian multivariat adalah analisis metode statistik yang memungkinkan kita melakukan penelitian terhadap lebih dari dua variabel secara bersamaan. Dengan menggunakan teknik analisis dapat menganalisis pengaruh beberapa variabel-variabel lainnya pada waktu yang bersamaan. Uji statistik yang digunakan adalah uji regresi logistik yaitu untuk mengetahui variabel independen yang mana lebih erat hubungannya dengan variabel dependen. Setelah melakukan seleksi analisis bivariat terdapat 5 variabel pemodelan multivariat dengan menggunakan metode forward.

Hasil penelitian terdapat pengaruh terhadap kejadian anemia pada remaja putri yaitu variabel kebiasaan sarapan, status gizi, asupan protein, pola konsumsi makanan inhibitor penyerapan zat besi dan lama haid yang merupakan hasil akhir dari analisis multivariat dengan menggunakan metode forward. Kekuatan hubungan dari besar yang terkecil adalah kebiasaan sarapan pagi adalah kebiasaan sarapan pagi $(\mathrm{OR}=8,583)$, status gizi $(\mathrm{OR}=5,301)$, asupan protein $(\mathrm{OR}=4,686)$, pola konsumsi makanan inhibitor penyerapan zat besi $(\mathrm{OR}=3,688)$ dan lama haid $(\mathrm{OR}=3,645)$ (Tabel 3). 
Tabel 3. Model Akhir Determinan Remaja Putri dengan Kejadian Anemia

\begin{tabular}{lrrrrrr}
\hline \multicolumn{1}{c}{ Variabel } & B & Wald & Df & Nilai $\boldsymbol{p}$ & Exp (B) & 95\% CI \\
\hline Kebiasaan Sarapan Pagi & 2.150 & 12.857 & 1 & 0,000 & 8,583 & $2,650-27,796$ \\
Status Gizi & 1.668 & 6.860 & 1 & 0,009 & 5,301 & $1,522-18,465$ \\
Asupan Protein & 1.545 & 6.328 & 1 & 0,012 & 4,686 & $1,407-15,612$ \\
Pola Konsumsi Makanan inhibitor Penyerapan & 1.305 & 4.686 & 1 & 0,037 & 3,688 & $1,079-12.607$ \\
Zat Besi & & & & & & \\
Lama Haid & 1.293 & 3.806 & 1 & 0,051 & 3,645 & $0,994-13,364$ \\
Constan & 3.398 & 15.826 & 1 & 0.000 & 0.033 & $2,650-27,796$ \\
\hline
\end{tabular}

\section{PEMBAHASAN}

Hasil penelitian menujukan bahwa dari 100 responden, yang mempunyai kadar hemoglobin dengan kategori anemia (jika nilai $\mathrm{Hb} \geq 12 \mathrm{~g} / \mathrm{dL}$ ) sebesar $33,0 \%$ atau tidak anemia (jika nilai $\mathrm{Hb} \leq 2 \mathrm{~g} / \mathrm{dL}$ ) sebesar $67,0 \%$ remaja putri. Anemia gizi besi adalah anemia yang terjadi akibat kekurangan zat besi dalam darah, artinya konsentrasi hemoglobin dalam darah berkurang karena terganggunya pembentukan sel-sel darah merah akibat kurangnya kadar besi dalam darah. Semakin berat kekurangan zat besi yang terjadi akan semakin berat pula anemia yang diderita (Gibney, 2008).

Temuan ini lebih kecil dari penelitian Suryani (2015), di Kota Bengkulu yaitu ditemukan sebanyak $43,0 \%$ remaja putri mengalami anemia. Anemia bukan merupakan pencerminan keadaan suatu penyakit atau gangguan fungsi tubuh. Secara fisiologis, anemia terjadi apabila terdapat kekurangan jumlah hemoglobin untuk mengangkut oksigen ke jaringan. Perempuan lebih rentan anemia dibanding dengan laki-laki Kebutuhan zat besi pada perempuan adalah 3 kali lebih besar daripada pada laki-laki (Smeltzer dan Bare, 2002).

Andriani M dan Wirjatmadi B (2013), menyatakan bahwa faktor-faktor yang mendorong terjadinya anemia gizi pada usia remaja yaitu adanya penyakit infeksi yang kronis, haid yang berlebihan pada remaja putri, pendarahan kecelakaan, jumlah makanan atau penyerapan diet yang buruk dari zat besi, vitamin B12, vitamin B6, vitamin C, dan tembaga.

Menurut Kemenkes RI (2013), menyebutkan anemia pada remaja putri menjadi masalah kesehatan bila prevalensinya $\geq 20 \%$ sedangkan prevalensi berdasarkan hasil penelitian sebanyak 33,0 (>20\%) sehingga anemia pada remaja putri di MTsN 02 merupakan masalah kesehatan yang perlu menjadi prioritas dalam penanggulangan sebelum kondisi memburuk.

Tingginya prevalensi anemia pada remaja putri di MTsN 02 Kota Bengkulu karena kurangnya asupan protein, zat besi dan mengalami haid berlebihan. Hal ini apabila tidak ada tindak lanjut dari dinas kesehatan terkait maka akan memberikan dampak negatif pada remaja putri di MTsN 02 Kota Bengkulu. Menurut Andriani dan Wirjatmadi (2013), remaja putri yang mengalami anemia akan berdampak seperti menurunnya tingkat prestasi belajar, terganggunya kegiatan belajar, menurunkan kesehatan reproduksi, perkembangan motorik, mental, tingkat kebugaran menurun dan tidak tercapainya tinggi badan yang maksimal.

Hasil penelitian dilakukan terhadap 100 responden didapatkan lebih dari setengahnya $(73,0 \%)$ dengan kategori haid tidak normal (jika lama haid $\geq 6$ hari) dan hampir setengah $(27,0 \%)$ remaja putri dengan haid normal (jika lama haid $>6$ hari), artinya gambaran lama haid pada remaja putri dengan kategori haid normal lebih banyak daripada remaja putri dengan kategori haid tidak normal.Temuan ini lebih kecil dari penelitian Febriana, dkk (2013), yaitu sebanyak $40 \%$ remaja putri mengalami lama haid tidak normal (haid $>6$ hari). Haid adalah pelepasan dinding rahim (endometrium) yang disertai dengan perdarahan dan terjadi setiap bulannya kecuali pada saat kehamilan. Haid yang terjadi setiap bulannya disebut sebagai siklus haid. Haid normal biasanya berlangsung 2-5 hari dan jika $>6$ sering disebut mengalami gangguan menoragia (Hestiantoro, 2008).

Faktor-faktor yang dapat mempengaruhi haid pada remaja putri adalah adanya gangguan fungsi hormon, kelenjar tiroid, kelainan sistemik pada wanita kurus dan gemuk dan managementstress yang tidak baik (Hazanah S, 2013). Gangguan haid pada remaja putri di MTsN 02 Kota Bengkulu adalah hipermoragia atau haid lebih dari 6 hari.

Hasil penelitian dilakukan terhadap 100 responden didapatkan responden yang memiliki status gizi normal (jika IMT/U $\leq+2 \mathrm{SD}$ dan $\leq 2$ ) sebanyak 57 responden $(57,0)$. Responden yang memiliki status gizi gizi tidak normal (jika $\mathrm{IMT} / \mathrm{U} \geq 2 \mathrm{SD}$ dan $\geq+2 \mathrm{SD}$ ) sebanyak 43 responden $(43,0 \%)$, artinya gambaran status gizi pada remaja putri di MTsN 02 Kota Bengkulu 
dengan kategori status gizi normal lebih banyak daripada status gizi tidak normal.

Temuan ini lebih kecil dari dengan penelitian yang dilakukan Mariana W (2013), ditemukan sebanyak $57,1 \%$ yang mempunyai gambaran status gizi remaja putri tidak normal. Status gizi merupakan suatu keadaan tubuh sebagai akibat antara konsumsi, penyerapan dan penggunaan zat-zat gizi atau keadaan fisiologik akibat tersedianya zat gizi dalam tubuh (Supariasa, 2002). Status gizi normal dapat dicapai dengan menyeimbangkan antara asupan, pengeluaran dan kebutuhannya (Proverawati, 2009).

Status gizi pada remaja akan masalah jika tidak normal karena status tidak gizi apabila dibiarkan tanpa ada kontrol dan tidak lanjut dalam penangannya maka akan menjadi masalah kesehatan (Waryana, 2010). Status gizi tidak normal di MTsN 02 Kota Bengkulu sebagian besar diakibatkan karena pola makan karena sebagian besar remaja putri sering mengonsumsi makanan jajanan yang tersedia di Sekolah sehingga tidak memperhatikan kecukupan kebutuhan nutrisi bahkan sebaliknya.

Gambaran kebiasaan sarapan remaja putri dari 100 responden lebih dari setengahnya $(61,0 \%)$ dengan kategori tidak baik (sarapan rutin dilakukan setiap hari) dan hampir setengahnya ditemukan sebanyak 39,0\%. Sehingga secara garis kebiasaan sarapan pagi remaja putri dengan kategori baik. Temuan ini lebih kecil dari penelitian Kalsum U dan Halim R (2016) yaitu sebanyak $60,0 \%$ remaja putri dengan kebiasaan sarapan pagi tidak baik.

Kebiasaan sarapan adalah tingkah laku manusia atau kelompok manusia dalam memenuhi kebutuhannya akan sarapan yang meliputi sikap, kepercayaan dan pemilihan makanan. Bagi sebagian orang sarapan merupakan kegiatan yang tidak menggairahkan karena nafsu makan belum ada. Selain itu, keterbatasan menu yang tersaji di meja makan dan waktu yang terbatas menyebabkan orang sering meninggalkan sarapan (Khomsan A, 2010). Kebiasaan sarapan terutama pada anak sangat dipengaruhi oleh perilaku orang tua dalam membiasakan anaknya sarapan di pagi hari (Ahmad dkk, 2011).

Kebiasaan sarapan di MTsN 02 Kota Bengkulu sejalan dengan teori Khomsan A (2010) karena berdasarkan hasil survei pada remaja putri yang sarapan pagi dikarenakan sudah terbiasa dari kecil dan letak geografis Sekolah jauh dari rumah sehingga orang tua remaja putri selalu menyediakan untuk sarapan pagi dan bekal apabila bangun kesiangan. kemudian remaja putri yang tidak sarapan sebagian menyatakan tidak sempat dan tidak terbiasa melakukan sarapan pagi.

Sarapan menjadi masalah apabila jarang dilakukan karena sarapan dapat bermanfaat sebagai pemberi energi untuk otak, memperbaiki daya ingat pada remaja putri dan gulanya akan menurun. Jika kondisi ini terjadi, maka tubuh akan berusaha menaikkan kadar gula darah dengan mengambil cadangan glikogen. Jika cadangan glikogen habis, maka cadangan lemaklah yang diambil (Moehji, 2009).

Selain itu, bila tidak sarapan pagi dapat menyebabkan konsentrasi belajar berkurang, kecepatan bereaksi menurun tajam sehingga kemampuan memecahkan suatu masalah juga menjadi sangat menurun yang akan menyebabkan prestasi belajar juga ikut menurun. Hal ini akan menghambat proses belajar di sekolah. Sehingga perlunya sosialisasi pentingnya kegiatan sarapan pagi.

Gambaran pendidikan ibu remaja putri secara garis besar mempunyai ibu berpendidikan rendah (SD, SMP dan SMA) yaitu dengan hasil persentase $92,0 \%$ dan pendidikan tinggi (D3, D4, S1, dst.) $8,0 \%$. Temuan ini jauh berbeda dengan hasil penelitian Martini (2015) yaitu sebanyak $60,0 \%$ remaja putri dengan ibu pendidikan rendah dan 40,0\% tingkat pendidikan ibu.

Tingkat pendidikan adalah tahap pendidikan yang berkelanjutan, yang ditetapkan berdasarkan tingkat perkembangan peserta didik, tingkat kerumitan bahan pengajaran dan cara menyajikan bahan pengajaran. Tingkat pendidikan sekolah terdiri dari pendidikan dasar, pendidikan menengah, dan pendidikan tinggi (Ikhsan, 2005).

Gunatmaningsih (2007) menyatakan bahwa pendidikan ibu berperan di dalam membangun kesehatan keluarga. ibu yang mempunyai pendidikan baik akan lebih mudah dalam menerima informasi kesehatan, baik dalam pangan maupun dalam hal pengasuhan anak. Pendidikan ibu merupakan modal utama dalam menunjang perekonomian keluarga, juga berperan dalam menyusun makanan keluarga, serta pengasuhan dan perawatan anak. Semakin tinggi pendidikan formal di harapkan semakin baik pula informasi kesehatannya, termasuk informasi kesehatan mengenai kebutuhan gizi keluarga.

Persentase gambaran asupan zat besi remaja putri tidak tercukupi sebanyak $70,0 \%$. Artinya remaja putri dengan asupan protein tidak tercukupi lebih banyak daripada remaja putri dengan asupan protein tercukupi. Hasil ini lebih besar dibandingkan penelitian yang dilakukan 
oleh Masthalina H (2015) yaitu sebanyak $49,25 \%$. Zat besi merupakan mineral mikro yang paling banyak di dalam tubuh manusia dan hewan, yaitu 3 sampai 5 gram di dalam tubuh orang dewasa. Asupan zat besi yang tidak memadai berarti kurangnya oksigen yang disampaikan ke jaringan-jaringan. Sebagai akibatnya, orang cepat merasa lelah, lesu dan tidak dapat berkonsentrasi dengan baik (Almatsier, 2002). Berdasarkan AKG 2013 asupan zat besi yang dianjurkan yaitu sebanyak 26mg/hari (Depkes RI, 2013).

Menurut besarnya masalah di MTsN 02 Kota Bengkulu gambaran asupan zat besi sebagian besar tidak tercukupi sehingga perlunya untuk sosialisasi dan upaya untuk meningkatan asupan makanan zat besi karena kekurangan zat besi sejak 30 tahun terakhir diakui berpengaruh terhadap produktivitas belajar, penampilan kognitif, dan sistem kekebalan remaja putri (Almatsier S, 2009).

Persentase gambaran asupan protein remaja putri tidak tercukupi (jika asupan protein $\succeq 69 \mathrm{~g} / \mathrm{hari}$ ) ditemukan sebanyak $45,0 \%$ dan $55,0 \%$ remaja putri dengan asupan protein tercukupi (jika asupan zat besi $226 \mathrm{mg} / \mathrm{hari}$ ). Temuan ini lebih besar dari penelitian yang dilakukan Paputungan dkk, (2016) yaitu sebanyak 27,6\% remaja putri dengan kategori asupan protein tidak tercukupi. Protein sangat bermanfaat bagi tubuh, karena memiliki berbagai macam fungsi seperti pertumbuhan dan pemeliharaan jaringan, membentuk senyawasenyawa esensial tubuh, mengatur keseimbangan air, mempertahankan kenetralan tubuh, membentuk antibodi dan mentranspor zat gizi (Cakrawati dan Mustika, 2012). Asupan protein dianjurkan untuk remaja remaja putri berdasarkan AKG (2013) usia 13-15 tahun 69g/hari.

Asupan protein akan menjadi salah satu faktor anemia jika asupan protein tidak tercukupi secara terus-menerus maka akan mempengaruhi keadaan status gizi remaja sehingga dapat mengakibatkan anemia pada remaja putri (Andriani M dan Wiratmadi B, 2013). Asupan protein remaja putri di MTsN 02 Kota Bengkulu hampir setangah $(45,0 \%)$ memiliki asupan protein tidak tercukupi. Hal ini terjadi karena remaja putri karena terbiasa mengonsumsi makan diluar rumah atau kantin sekolah seperti nasi uduk, mie instan dan gorengan (bakwan, tahu, pisang goreng, ubi goreng) sehingga konsumsi lauk hewani rata-rata konsumsi lauk hewani $\mathcal{S}$ porsi/hari.

Gambaran pola konsumsi makanan inhibitor penyerapan zat besi ditemukan sebanyak 54,0\% dengan pola konsumsi inhibitor penyerapan zat besi kategori sering (jika nilai

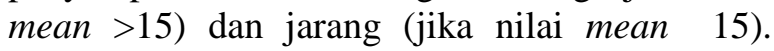
Artinya lebih dari setengah remaja putri di MTsN 02 Kota Bengkulu dengan pola konsumsi inhibitor penyerapan zat besi kategori tidak tercukupi lebih banyak daripada remaja putri dengan pola konsumsi inhibitor penyerapan zat besi kategori tercukupi. Hal ini terjadi karena remaja putri sering mengonsumsi makanan yang banyak mengandung zat penghambat zat besi seperti fitat (jagung, kedelai dan jenis kacangkacangan yang lainnya), tannin (pada teh, kopi, bayam) dan zat kapur/kalsium (susu dan keju) dapat menghambat penyerapan zat besi (Soekirman, 2000).

Temuan ini sejalan dengan penelitian yang dilakukan oleh Paputungan dkk (2016) yang menemukan sebesar $51,4 \%$. Secara umum asupan makanan dapat mempengaruhi defisiensi zat besi sehingga mengakibatkan anemia. Defisiensi zat besi dipengaruhi oleh beberapa faktor lainnya seperti kondisi non gizi (kelainan genetik, penyakit infeksi serta cacingan) dan gizi karena ada makanan yang bersifat menghambat penyerapan zat besi seperti makanan yang mengandung senyawa tanin, fitat, polizat besinol, oksalat dan serat pangan yang banyak terdapat pada teh dan serealia (Departemen Gizi dan Kesehatan Masyarakat, 2012).

\section{Lama Haid Remaja Putri}

Hasil analisis bivariat dengan uji chisquare $(2 \times 2)$ menunjukkan adanya hubungan bermakna antara lama haid dengan kejadian anemia pada remaja putri di MTsN 02 Kota Bengkulu $(p=0,028)$. Hal ini sejalan dengan penelitian dilakukan oleh Febriayanti dkk, (2013) menunjukkan terdapat hubungan yang bermakna antara lama haid dengan kejadian anemia pada remaja putri $(p=0,028)$.

Haid adalah pelepasan dinding rahim (endometrium) yang disertai dengan perdarahan dan terjadi setiap bulannya kecuali pada saat kehamilan. Haid yang terjadi setiap bulannya disebut sebagai siklus haid. Haid biasanya terjadi pada usia 11 tahun dan berlangsung hingga menopause (biasanya terjadi sekitar usia 45-55 tahun) (Sibagariang, 2010). Pada kenyataanya, tidak semua remaja putri di MTsN 02 Kota Bengkulu memiliki siklus haid yang normal. Banyak diantara mereka yang siklus haid teratur, yakni tidak memiliki siklus tertentu.

Gangguan haid dalam penelitian ini yang paling banyak pada remaja putri adalah hipermenoria. Hal ini terjadi karena remaja putri mengalami mentruasi yang berlebihan yakni 
pendarahan haid lebih banyak dari normal (lebih dari 6 hari). Menurut Juanita (2010) sebab kelainan ini terletak pada kondisi dalam uterus, misalnya adanya mioma uteri dengan permukaan endometrium yang lebih luas dan dengan kontraktilitas yang terganggu, gangguan pelepasan endometrium pada waktu haid.Gangguan pelepasan endometrium yang diikuti dengan gangguan pelepasan pada waktu haid.

Terdapat $73,0 \%$ remaja putri yang tidak mengalami haid normal, hal ini terjadi karena haid yang terjadi pada remaja putri teratur setiap bulan dan jumlah lama hari pendarahanya normal. hal ini dimungkinkan karena remaja putri menjaga pola makan, banyak berolahraga, banyak beristirahat dan tidak mengalami stress.

Hasil analisis bivariat dengan uji chisquare $(2 \times 2)$ menunjukkan ada hubungan yang bermakna antara status gizi dengan kejadian anemia pada remaja putri $(p=0,000)$. Hal ini sejalan dengan penelitian yang dilakukan oleh Martini (2015) menunjukkan adanya hubungan yang bermakna antara status gizi dengan kejadian anemia pada remaja putri $(p=0,009)$. Status gizi merupakan keadaan tubuh sebagai akibat antara konsumsi, penyerapan dan penggunaan zat-zat gizi atau keadaan fisiologik akibat dari tersedianya zat gizi dalam tubuh. Pada penelitian ini sebagian besar subyek memiliki status gizi normal (jika nilai IMT/U $\leq 2 \mathrm{SD}$ dan $\leq+2 \mathrm{SD}$ ) $57,0 \%$ dengan anemia sebanyak 10 responden $(17,0 \%)$ dan 47 responden $(82,5 \%)$ tidak mengalami anemia. Kategori remaja putri tidak normal (jika IMT/U >-2 SD dan > +2 SD) dengan anemia 23 responden $(53,5 \%)$ dan 20 responden $(46,5 \%)$ tidak anemia. Hal ini terjadi karena remaja putri di MTsN 02 Kota Bengkulu mempunyai pola makan yang baik dan kebutuhan nutrisi terpenuhi sehingga status gizi normal dan sebaliknya remaja putri dengan status gizi tidak normal mempunyai pola makan dan asupan yang kurang baik. Hal ini sesuai dengan teori Hapzah dan Yulita (2012), menyatakan bahwa pada dasarnya anemia dipengaruhi secara langsung oleh konsumsi makanan sehari-hari yang kurang mengandung zat besi selain faktor infeksi sebagai pemicunya. Secara umum makanan berkaitan erat dengan yang baik, maka status gizi juga normal, sebaliknya bila makanan yang dikonsumsi kurang nilai gizinya, makan akan menyebabkan kekurangan nilai gizinya dan dapat menimbulkan anemia (Supariasa, 2002).

Beberapa faktor yang memicu terjadinya masalah gizi pada usia remaja seperti kebiasaan makan yang salah, pemahaman gizi yang keliru dimana tubuh yang langsing menjadi idaman para remaja sehingga kebutuhan gizi tidak terpenuhi, dan kesukaan yang berlebihan terhadap makanan tertentu contohnya makanan cepat saji (fast food) (Supariasa, 2002). Menurut Thompson (2007), status gizi mempunyai korelasi positif dengan konsentrasi hemoglobin, artinya semakin buruk status gizi seseorang maka semakin rendah kadar Hbnya. Berdasarkan penelitian di MTsN 02 Kota Bengkulu ditemukan hubungan yang bermakna antara IMT/U dengan kejadian anemia pada remaja putri , yang mana remaja putri dengan IMT/U tergolong tidak normal memiliki resiko 5,405 kali. Hasil temuan ini lebih besar dari penelitian Martini (2015) bahwa remaja putri dengan status gizi tidak normal memiliki peluang mengalami anemia sebesar 3,1 kali mengalami anemia.

Terkait dengan sarapan pagi, hasil penelitian menunjukkan bahwa terdapat hubungan yang bermakna antara sarapan pagi dengan kejadian anemia pada remaja putri $(p=0,000)$. Sarapan adalah kegiatan makan dan minum yang dilakukan antara bangun pagi sampai jam 9 untuk memenuhi sebagian kebutuhan gizi harian (15-30\% kebutuhan gizi) dalam rangka mewujudkan hidup sehat, aktif dan produktif. Masyarakat Indonesia masih banyak yang belum membiasakan sarapan. Padahal dengan tidak sarapan akan berdampak buruk terhadap proses belajar di sekolah bagi anak sekolah, menurunkan aktifitas fisik, menyebabkan kegemukan pada remaja, orang dewasa dan meningkatkan risiko jajan yang tidak sehat (Kemenkes RI, 2014). Kebiasaan sarapan pagi dalam penelitian ini di MTsN 02 Kota Bengkulu ditemukan bahwa sebagian besar remaja putri dengan kebiasaan sarapan tidak baik mengalami anemia sebanyak 25 responden $(64,1 \%)$ sedangkan remaja putri tidak anemia dengan kebiasaan sarapan pagi baik mengalami anemia sebanyak 8 responden $(12,1 \%)$, artinya remaja yang mempunyai kebiasaan sarapan yang tidak baik akan cenderung lebih banyak mengarah ke anemia. Hal ini sesuai dengan teori Khomsan (2010) bahwa adanya korelasi hubungan yang positif antara kebiasaan sarapan pagi dengan kejadian anemia pada remaja putri.

Tidak sarapan pagi akan menyebabkan tubuh tidak mempunyai energi yang cukup untuk melakukan aktivitas terutama pada proses belajar karena pada malam hari di tubuh tetap berlangsung proses oksidasi guna menghasilkan tenaga untuk menggerakkan jantung, paru-paru dan otot-otot tubuh lainnya. Remaja putri yang melewatkan waktu sarapan akan mengalami gangguan fisik terutama kekurangan energi untuk beraktivitas (Moehji, 2009). 
Dampak dirasakan remaja putri apabila sarapan tidak baik maka pada saat proses belajar menjadi kurang konsentrasi, mudah lelah, mudah mengantuk dan gangguan fisik lainnya. Remaja putri yang sarapan memiliki performa yang lebih baik dalam perkembangan kognitif di Sekolah dibandingkan mereka yang tidak sarapan (Ahmad dkk, 2011).

Hasil analisis bivariat dengan uji chisquare $(2 \times 2)$ menemukan bahwa tidak terdapat hubungan yang bermakna antara pendidikan ibu dengan kejadian anemia pada remaja putri $(p=0,265)$. Hasil temuan ini bertolak belakang dengan penelitian yang dilakukan oleh Martini (2015), menemukan bahwa terdapat hubungan yang bermakna antara pendidikan ibu dengan kejadian anemia pada remaja putri $(p=0,036)$ dan teori dari Gunatmaningsih (2007) menyatakan bahwa pendidikan ibu berperan di dalam membangun kesehatan keluarga. ibu yang mempunyai pendidikan baik akan lebih mudah dalam menerima informasi kesehatan, baik dalam pangan maupun dalam hal pengasuhan anak. Pendidikan ibu merupakan modal utama dalam menunjang perekonomian keluarga, juga berperan dalam menyusun makanan keluarga, serta pengasuhan dan perawatan anak. Semakin tinggi pendidikan formal di harapkan semakin baik pula informasi kesehatannya, termasuk informasi kesehatan mengenai kebutuhan gizi keluarga.

Hal ini mungkin terjadi karena pendidikan secara formal tidak mempengaruhi tingkat pengetahuan kesehatan dan perilaku ibu menyikapi pola makan dan hidup sehat. Pengetahuan kesehatan dengan perkembangan teknologi media informasi saat ini sangat mudah untuk ibu mendapatkan informasi melalui media internet dan televisi sehingga meskipun pendidikan ibu rendah tetapi tidak dengan pengetahuan kesehatan, oleh sebab itu meskipun ibu berpendidikan rendah tidak mempengaruhi remaja putri mengalami anemia.

Asupan zat besi remaja berhubungan yang bermakna dengan kejadian anemia pada remaja putri $(p=0,000)$. Penelitian ini sejalan dengan penelitian Paputungan SR, dkk (2016) menyatakan bahwa adanya hubungan yang bermakna antara asupan zat besi dengan kejadian anemia pada remaja putri dengan nilai $p=0,001$. Remaja putri yang mempunyai asupan zat besi kurang akan lebih rentan terkena anemia di bandingkan dengan remaja putri yang memenuhi kebutuhan zat besi.

Zat besi merupakan komponen utama yang memegang peranan penting dalam pembentukan darah (hemopoiesis), yaitu mensintesis hemoglobin. Kelebihan besi disimpan sebagai protein ferritin, hemosiderin di dalam hati, sumsum tulang belakang dan selebihnya di dalam limpa dan otot. Apabila simpanan besi cukup maka kebutuhan untuk pembentukan sel darah merah sumsum tulang akan terpenuhi. Namun, apabila jumlah simpanan zat besi berkurang dan jumlah zat besi dalam tubuh, akibatnya kadar hemoglobin menurun di bawah normal yang disebut sebagai anemia gizi besi. Kebutuhan zat besi juga mengalami peningkatan pada remaja putri hingga 1,4 mg pada saat haid berlangsung (Gibney, 2008).

Hasil penelitian asupan zat besi yang diperoleh dengan recall 24 jam selama 2 hari diketahui bahwa sebagian besar remaja putri dengan dengan kategori tidak tercukupi lebih banyak mengalami anemia (45,7\%) dibandingkan dengan remaja putri dengan asupan zat besi kategori tercukupi $(3,3 \%)$, artinya dapat disimpulkan bahwa remaja putri dengan asupan zat besi tidak tercukupi cenderung lebih banyak mengarah dengan kejadian anemia. Hal dengan teori Almatsier (2009), menyatakan bahwa zat besi mempunyai beberapa fungsi esensial di dalam tubuh pada remaja putri. Kekurangan zat besi secara terus menerus akan mengakibatkan anemia sehingga dapat memberikan dampak negatif terhadap sistem kekebalan tubuh dan penampilan kognitif.

Zat besi yang baik dapat dipenuhi dengan sering mengonsumsi makanan hewani seperti daging, ayam dan ikan. Sumber baik lainnya adalah telur, serealia tumbuk, kacang-kacangan, sayuran hijau, dan beberapa jenis buah. Disamping jumlah besi, perlu diperhatikan pula kualitas besi dalam makanan dan ketersediaan biologiknya (Almatsier, 2002).

Hasil analisis bivariat dengan uji chisquare $(2 \times 2)$ menemukan bahwa terdapat hubungan yang bermakna antara asupan protein dengan kejadian anemia pada remaja putri $(p=0,017)$. Penelitian ini jalan dengan penelitian Paputungan SR, dkk (2016), menemukan bahwa terdapat hubungan antara asupan protein dengan kejadian anemia pada remaja putri $(p=0,003)$. Pembentukan hemoglobin sangat tergantung dengan ketersediaan bahan bakunya yaitu protein zat besi dan vitamin C. Almatsier (2009), menyatakan bahwa protein berperan penting dalam transportasi zat besi di dalam tubuh. Oleh karena itu, kurangnya asupan protein akan mengakibatkan transportasi zat besi terhambat sehingga akan terjadi defisiensi zat besi sehingga mengakibatkan anemia. Disamping itu makanan yang tinggi protein terutama berasal dari hewani banyak mengandung zat besi. 
Asupan protein dalam penelitian di MTsN 02 Kota Bengkulu ditemukan bahwa sebagian besar remaja putri dengan asupan protein tidak tercukupi mengalami anemia lebih banyak $(53,3 \%)$ dibandingkan dengan remaja putri dengan kategori tercukupi $(16,4 \%)$. Hal ini terjadi karena asupan protein merupakan zat makanan yang amat penting bagi tubuh berfungsi sebagai zat pembangun dan pengatur. Asupan protein yang adekuat sangat penting untuk mengatur intergritas, fungsi, dan kesehatan manusia dengan menyediakan asam amino sebagai precursor molekul esensial yang merupakan komponen dari semua sel dalam tubuh (Cakrawati dan Mustika, 2012).

Ada hubungan yang bermakna antara pola konsumsi makanan inhibitor dengan kejadian anemia pada remaja putri $(p=0,034)$. Penelitian ini sejalan dengan penelitian Masthalina $\mathrm{H} \mathrm{dkk}$, (2015) $p=0,004$ artinya terdapat hubungan antara pola konsumsi makanan inhibitor penyerapan zat besi dengan kejadian anemia pada remaja putri sehingga dapat dikatakan bahwa remaja putri yang sering mengonsumsi makanan inhibitor penyerapan zat besi maka kejadian anemia tinggi dan sebaliknya jika remaja putri jarang mengonsumsi makanan inhibitor penyerapan zat besi maka kejadian anemia rendah.

Hal ini disebabkan karena sebagian besar remaja putri di MTsN 02 Kota Bengkulu sering mengkonsumsi makanan atau minuman yang merupakan sumber penghambat penyerapan $\mathrm{Fe}$ (inhibitor) yaitu tanin dan oksalat yang banyak terkandung dalam makanan seperti kacangkacangan, pisang, bayam, coklat, kopi, dan teh. Remaja putri di MTsN 02 Kota Bengkulu sering mengonsumsi pisang goreng coklat hampir setiap hari dengan frekuensi $>1 \mathrm{x}$ sehari dan dari 100 responden ada 26 orang $(26,0 \%)$ yang biasa mengonsumsi pisang, selain itu juga remaja putri di MTsN 02 Kota Bengkulu suka mengonsumsi teh sehabis makan dari responden ada 67 orang (67\%) yang biasa mengonsumsi teh. Hal ini mungkin yang menyebabkan adanya hubungan antara mengonsumsi makanan sumber penghambat $\mathrm{Fe}$ atau Inhibitor dengan status anemia Remaja putri di MTsN 02 Kota Bengkulu.

Hasil penelitian ini sejalan juga dengan penelitian Utomo (2013), di SMAN 1 Mojolaban ditemukan siswi yang anemia sebanyak $61,9 \%$ mengonsumsi teh sering, siswi yang tidak anemia yang mengonsumsi teh setiap hari sebanyak $58,3 \%$. Teh merupakan minuman yang mengandung tanin yang dapat menurunkan penyerapan besi non hem dengan membentuk ikatan komplek yang tidak dapat diserap
(Temme, 2002). Penelitian Thankachan (2008), pada wanita menyimpulkan bahwa konsumsi teh 1-2 cangkir sehari menurunkan absorpsi besi, baik pada wanita dengan anemia ataupun tidak. Konsumsi 1 cangkir teh sehari dapat menurunkan absorbsi Fe sebanyak 49\% pada penderita anemia defisiensi besi, sedangkan konsumsi 2 cangkir teh sehari menurunkan absorbasi $\mathrm{Fe}$ sebesar $67 \%$ pada penderita anemia defisiensi $\mathrm{Fe}$ dan $66 \%$ pada kelompok kontrol.

Berdasarkan teori Syamsir (2006) menyebutkan bahwaasam fitat dan senyawa fitat dapat mengikat mineral seperti kalsium, magnesium, seng dan tembaga sehingga berpotensi mengganggu penyerapan mineral. Selain mengikat mineral, fitat juga bisa berikatan dengan protein sehingga menurunkan nilai cerna protein. Kandungan fitat di dalam biji-bijian dan kacang-kacangan relatif tinggi. Asam fitat dapat menyebabkan seseorang defisiensi mineral dan protein. Defisiensi terjadi jika makanan tersebut rutin dikonsumsi sementara menu makan tidak bervariasi (dan sebagian besar berupa pangan serealia dan kacangan-kacangan). Fitat bisa di hidrolisis dengan bantuan asam atau enzim (indigenus atau eksogenus). Ini sebabnya mengapa proses perkecambahan dan fermentasi (seperti pada pembuatan tempe) bisa mereduksi kadar fitat di dalam bahan makanan tersebut (Syamsir, 2006).

\section{Faktor Dominan yang Mempengaruhi Kejadian Anemia pada Remaja Putri}

Hasil penelitian dengan menggunakan regresi logistik diperoleh bahwa status gizi merupakan salah satu faktor yang paling dominan mempengaruhi kejadian anemia pada remaja putri dengan peluang 6,33 kali pada remaja putri dengan status gizi kategori tidak normal. Hasil penelitian ini lebih besar dari penelitian yang dilakukan oleh Martini $(20,15)$ dengan remaja putri yang memiliki status gizi tidak normal akan memiliki peluang anemia sebanyak 3,1 kali. Artinya semakin banyak remaja putri dengan status gizi baik maka peluang anemia akan rendah sebaliknya jika status gizi remaja putri banyak tidak normal maka peluang kejadian anemia akan terus meningkat.

Thompson (2007)menyebutkan, status gizi mempunyai korelasi positif dengan konsentrasi Hemoglobin, artinya semakin buruk status gizi seseorang maka semakin rendah kadar Hbnya. Berdasarkan penelitian di MTsN 02 Kota Bengkulu ditemukan hubungan yang bermakna antara IMT/U dengan kejadian anemia pada remaja putri, yang mana remaja putri dengan 
IMT/U tergolong tidak normal memiliki resiko 5,405 kali. Hasil temuan ini lebih besar dari penelitian Martini (2015) bahwa remaja putri dengan status gizi tidak normal memiliki peluang mengalami anemia sebesar 3,1 kali mengalami anemia.

Hal ini terjadi karena remaja putri di MTsN 02 Kota Bengkulu mempunyai pola makan yang baik dan kebutuhan nutrisi terpenuhi sehingga status gizi normal dan sebaliknya remaja putri dengan status gizi tidak normal mempunyai pola makan dan asupan yang kurang baik. Hal ini sesuai dengan teori Hapzah dan Yulita (2012), menyatakan bahwa pada dasarnya anemia dipengaruhi secara langsung oleh konsumsi makanan sehari-hari yang kurang mengandung zat besi selain faktor infeksi sebagai pemicunya. Secara umum makanan berkaitan erat dengan yang baik, maka status gizi juga normal, sebaliknya bila makanan yang dikonsumsi kurang nilai gizinya, makan akan menyebabkan kekurangan nilai gizinya dan dapat menimbulkan anemia (Supariasa, 2002).

\section{DAFTAR PUSTAKA}

Ahmad, S., Waluyo \& Fatima F. 2011. Hubungan Kebiasaan Sarapan dan Kue status gizi anak-anak di sekolah dasar SDN Kledokan Depok Sleman. University Journal Respati Yogyakarta. Vol. 1 No. 1.

Almatsier S. 2002. Prinsip Dasar Ilmu Gizi. Jakarta: Gramedia.

2009. Prinsip Dasar Ilmu Gizi. Jakarta: Gramedia Cetakan IX.

Andriani. M dan Wirjatmadi B. 2013. Pengantar Gizi Masyarakat. Jakarta: Kencana Pranada Media Grup.

Arisman MB. 2010. Gizi Daur Kehidupan. Jakarta: Buku Kedokteran Cetakan XII. Penerbit EGC.

Cakrawati D, NH Mustika. 2012. Bahan Pangan, Gizi dan Kesehatan. Bandung: Penerbit Alfabeta.

Depkes RI. 2013. Tabel Angka Kecukupan Gizi. http://gizi.depkes.go.id (Diakses 20 Februari 2017).

Gibney. 2008. Gizi Kesehatan Masyarakat. Jakarta: ECG.

Gunatmaningsih, D. 2007. Faktor-faktor yang Berhubungan Dengan Kejadian Anemia Pada Remaja Putri Di SMA Negeri 1 Kecamatan Jatibarang Kabupaten Brebes

\section{SIMPULAN}

Hasil penelitian menunjukkan kejadian anemia pada remaja putri di MTsN 02 Kota Bengkulu berjumlah $33,0 \%$ dari 100 orang. Faktor yang berhubungandengankejadian anemia pada remaja putri adalah kebiasaan sarapan pagi, status gizi, asupan protein, pola konsumsi makanan inhibitor penyerapan zat besi dan lama haid.

\section{SARAN}

Perlu upaya peningkatan pencegahan anemia pada program UKS terhadap anemia pada remaja putri di MTsN 02 Kota Bengkulu berkerja sama dengan intitusi terkait, seperti Puskesmas untuk melakukan pemeriksaan $\mathrm{Hb}$ kepada remaja putri (sisiwi) secara berskala dan memberikan penyuluhan tentang perlunya asupan protein tercukupi. Kepada pihak MTsN 02 Kota Bengkulu pentingnya melakukan rujukan terhadap remaja putri (siswi) yang terlihat tanda dan gejala anemia ke fasilitas kesehatan, seperti Puskesmas.

Tahun 2007. Doctoral dissertation, Universitas Negeri Semarang.

Hestiantoro, A. Dkk. 2008. Masalah Gangguan Haid dan Infertilitas. Jakarta: FKUI.

Hapzah \& Yulita, R. 2012. Hubungan Tingkat Pengetahuan dan Status Gizi terhadap Kejadian Anemia Remaja Putri pada Siswi Kelas III di SMA N 1 Tinambung Kabupaten Polewali Mandar. JurnalMedia Gizi Pangan, Volume 4 No.12.

Hazanah S, Rahmawati S, Nurlaila. 2013. Hubungan stress dengan siklus menstruasi pada usia 18-21 tahun. Jurnal Husada Mahakam, Volume 3 (7), p 331-339.

Ikhsan. 2005. Dasar-dasar Kependidikan. Jakarta: PT. Rineka Cipta.

Kalsum, U., \& Halim, R. Kebiasaan Sarapan Pagi berhubungan dengan Kejadian Anemia pada Remaja di SMA Negeri 8 Muaro Jambi. Jurnal Penelitian Universitas Jambi: Seri Sains, Vol.18, No.1, 2016.

Kemenkes RI. 2013. Riset Kesehatan Dasar. http://www.depkes.go.id (Diakses 20 Februari 2017).

. 2014. Pedoman Gizi Seimbang. http://gizi.depkes.go.id/ (Diakses 7 Februari 2017). 
Khomsan, A. 2010. Pangan dan Gizi untuk Kesehatan. Jakarta: Raja Grafindo Persada.

Mariana W dan Nur Khafidhoh. 2013. Hubungan Status Gizi dengan Kejadian Anemia pada Remaja Putri di SMK Swadaya Wilayah Kerja Puskesmas Karang Doro Kota Semarang Tahun 2013. Jurnal Kebidanan Volume 2 Nomor 4.

Martini, M. 2015. Faktor-faktor yang Berhubungan dengan Kejadian Anemia pada Remaja Putri di MAN 1 Metro. Jurnal Kesehatan Metro Sai Wawai, 8(1), p 1-7.

Moehji. 2009. Ilmu Gizi 2. Jakarta: Papas Sinar Sinarti.

Paputungan SR, Kapanto NH dan Rattu. 2016. Hubungan Antara AsupanZatBesidan Protein denganKejadian Anemia pada Siswa Kelas VIII dan Kelas IX di SMP Negeri 8 Manado. Jurnal Ilmiah Pharmacon, Volume 5 Nomor 1.

Proverawati dan Asfuah. 2009. Gizi untuk Kebidanan. Yogyakarta: Muha Medika.

Sibagariang. 2010. Kesehatan Reproduksi Wanita. Jakarta: Trans Media Info.

Soekirman. 2000. Ilmu Gizi dan Aplikasinya. Jakarta: Direktorat Jenderal Pendidikan Tinggi, Departemen Pendidikan Nasional.

Suryani, D., Hafiani R., \& Junita R. 2015. Analisis Pola Makan dan Anemia Gizi Besi pada Remaja Putri Kota
Bengkulu. Jurnal Kesehatan Masyarakat Andalas, 10(1), p 11-18.

Smeltzer. dan Bare. 2002. Buku Ajar Keperawatan Medikal Bedah. Brunner dan Suddarth (Ed.8, Vol. 1,2). Jakarta: EGC.

Supariasa I.DN, dkk. 2002. Penilaian Status Gizi. Buku Kedokteran. Jakarta: EGC.

Syamsir E. 2006. Panduan Praktikum Pengolahan Pangan. Departemen Ilmu dan Teknologi Pangan. Fateta IPB. Bogor.

Temme EHM danHoydonck PGA Va. 2002. Tea Consumption and Iron Status. European Journal of Clinical Nutrition. 56, p 376386.

Thankachan, et al. 2008. Iron Absorbtion in Young Indian Women: The Interaction of Iron Status with The Influence of Tea and Ascorbic Acid. The American Journal of Clinical Nutrition. 87: 881-886.

Thompson. 2007. The Quest for Competititve Advantage. Sixteenth Edition. McGrawHill International Edition.

Utomo. 2013. Hubungan antara Asupan Protein, vitamin C, dan Kebiasaan Minum Teh dengan Kejadian Anemia pada Remaja Putri di SMA Negeri 1 Mojolaban, Kabupaten Sukoharjo Jawa Tengah. Skripsi, Fakultas Ilmu Kesehatan Masyarakat UNS.

Waryana. 2010. Gizi Reproduksi. Yogyakarta: Graha Ilmu. 